\title{
PREPARING STUDENTS TO BECOME RESPONSIBLE CITIZENS
}

\author{
Oleh: Diyantari* \& Irawaty ${ }^{*}$
}

\begin{abstract}
Character building is one of the most important issues in education. The Government of Indonesia states clearly the issue of preparing responsible citizens in the regulations of its national education system. This research aims at investigating what teachers should do in classroom in order to prepare students to become responsible citizens. It is a qualitative research in which the data is gathered through library research. It can be concluded that teachers should develop democratic classroom rules and clear expectations, share responsibility, set clear goals and plans, take a problem-solving approach, encourage students to care for others, encourage students to compete with themselves to achieve their personal best, involve students in community activities, and keep a journal to evaluate in order to prepare students to become responsible citizens through well prepared classroom management.
\end{abstract}

Keywords: Classroom management, responsible citizens, character building.

*English Literature Study Program Universitas Negeri Jakarta. Email: dy_unj@yahoo.com

-Pancasila and Civic Education Study Program Universitas Negeri Jakarta. Email: irawaty@unj.ac.id/iraunj@gmail.com 


\section{INTRODUCTION}

Character building is a very important part in education that it must be embedded in all subjects in school and university. It is very important for students not only to master the content and skills of the subjects they learn but also to build characters because a knowledgeable person without positive characters can be dangerous. One of the must-have characters is being responsible.

In the Constitution of Indonesia, education is stated in Article 31. Based on what is stated in the article, all Indonesian citizens have the right to get education. As for elementary level, the education should be free of charge. Furthermore, the article also states that the government provides one education national system. Based on the Constitution, the government of Indonesia establishes laws and regulations to implement the national education system.

There was Law Number 2 Year 1989 regarding National Education System, which has been amanded with the Law Number 20 Year 2003 regarding National Education System. Article 3 of the latest Law states the functions of the national education, as elaborated below:
"Pendidikan nasional berfungsi mengembangkan kemampuan dan membentuk watak serta peradaban bangsa yang bermartabat dalam rangka mencerdaskan kehidupan bangsa, bertujuan untuk berkembangnya potensi peserta didik agar menjadi manusia yang beriman dan bertakwa kepada Tuhan Yang Maha Esa, berakhlak mulia, sehat, berilmu, cakap, kreatif, mandiri, dan menjadi warga negara yang demokratis serta bertanggung jawab."

Based on the aforementioned article, one of the functions of the education in Indonesia is to help students to develop in order to become responsible citizens. In order to implement such function, the government of Indonesia set some compulsory subjects at all level of education. Those courses as stated on Article 37 (1) and (2) are: Pendidikan Agama (religion subjects), Pendidikan Kewarganegaraan (civic education) and Bahasa (language).

In implementing those subjects at the university level, the General Director of Higher Education gives guidance as stated in Keputusan Direktur Jenderal Pendidikan Tinggi Nomor: 43/DIKTI/Kep/2006 tentang Rambu-Rambu Pelaksanaan Kelompok Matakuliah Pengembangan Kepribadian di Perguruan Tinggi. The Article 2 of the aforementioned 
Keputusan states that: "Misi kelompok MPK di perguruan tinggi membantu mahasiswa memantapkan kepribadiannya agar secara konsisten maтри mewujudkan nilai-nilai dasar keagamaan dan kebudayaan, rasa kebangsaan dan cinta tanah air sepanjang hayat dalam menguasai, menerapkan dan mengembangkan ilmu pengetahuan, teknologi dan seni yang dimilikinya dengan rasa tanggung jawab." (The missions of the courses of character development at university help students to bring out the best of their characters so that they could consistently realize basic values of religion and culture, nationalism, apply and develop science, technology and art which they have withresponsibility)

Based on that article, students need to bring out their best personalities or characters so that the qualities that they achieve could be used with full responsibility. However, the Government of Indonesia amanded the compulsory subjects through The Law Number 12 Year 2012 regarding Higher Education. Article 35 (3) states four mandatory courses which must be taken by university students, they are: Religion (Agama); the Five Principles (Pancasila); Kewarganegaraan (Civic Education); and Indonesian languange (Bahasa Indonesia). This article amanded the compulsory subjects which were regulated through Keputusan Direktur Jenderal Pendidikan Tinggi Nomor: 43/DIKTI/Kep/2006 ( which has been mentioned before).

Article 3 of the Law of Higher Education of 2012 states that there are 9 (nine) principles of higher education, which are: scientific truth (kebenaran ilmiah), logic (penalaran), honesty (kejujuran), fairness (keadilan), benefit (manfaat), kindness (kebajikan), responsibility (tanggung jawab), diversity (kebhinnekaan), and affordability (keterjangkauan). Thus, one of those principles which is clearly stated is responsibility.Therefore, it is important to make sure that students are being responsible in classroom because “it serves as a means of preparing students to take their place in society as responsible citizens, an aim of primary importance to schooling" (Rothstein in Lewis et.al, 2005: p. 729).

Classroom is a good place where they can learn and practise on becoming responsible citizens. According to Hattie (2009), based on his research which incorporates studies of several million students, "teachers are among the most powerful influences in learning" (in Roffey, 2011). More or less one third of children's time is spent 
in school. Therefore, besides parents, school has a great influence in shaping students' characters. What teachers do in classroom affects students' characters. Teachers have to give good examples to students so that students build good characters. As it is often said, teachers should be role models for their students. The writer believes that knowledge without strong positive characters will not bring positive impact to students and society.

Teachers' characters can be seen from the way they manage their classroom. Therefore, teachers have to carefully plan their classroom management so that the students see the reflections of teachers' positive characters which can encourage students to have positive characters as well. The writer believes that classroom management functions are not only to make sure that the learning of the subject matters occurs effectively, but also to build students' characters that prepares them to be become responsible students in and outside the classroom. It means that it is expected that they will be responsible persons in their community and in the bigger scope, it prepares them to be responsible citizens. This article will discuss what teachers should do in the classroom in order to prepare students to become responsible citizens.

\section{Classroom Management}

The traditional goal of classroom management has been focusing on the academic instruction in which teachers have to maintain and enforce discipline so that academic instruction can proceed without distractions. It was teacher and instruction-centered, not student-centered. Recently, schools are increasingly focused on social and emotional learning, as well as academic learning. Classroom management strategies must both maintain order and foster learning. (Bear 2005 Brophy, 1999, Curwin and Mendler 1988 Dreikurs 1968, Freiberg 1999b, Glasser, 1992, Gordon, 1974, 2003, Kohn 1996, Weinstein 1999 in Elias \& Schwab, 2006).Learning can mean the learning of the subject matters and it can also mean the building of characters of the students.

Lewis and Lovegrove (1989) argue that classroom management can be defined as managerial and educational. Classroom management can be defined as managerial when it functions as a means to the important end of facilitating the learning of school subjects by minimising students' offtask behaviour with predominance 
given to the legal/rational authority of the teacher. In this sense, classroom management is needed to make sure that all students do what they have to in order to achieve effective and efficient learning of the subject matter. It can be defined as educational when it is rights based and it emphasizes on management performing an educational functions in which the students learn the values from the experience they have related to classroom management, among them are equity, participation, enquiry and debate. The values that students learn from classroom management teachers apply will prepare them to become responsible students.

\section{Responsible Citizen}

Article 29 of the Convention on the Rights of the Child states that children have the right to "the development of the child's personality to its fullest potential; the preparation of the child for a responsible role in society; the development of respect for nature; mutual understanding and friendship among all peoples; and especially the development of respect for human rights and fundamental freedoms. (inGarratt \& Piper, 2003, p. 139)

It is stated that the preparation of children for a responsible role in society is not only needed to be given to them, but it is their right, and it is our responsibility as educators to give children their rights. According to Tshabangu (2006), responsible citizens participate in solving problems existing in their world, have the ability to empathise (to walk in someone's shoes) and are rational. They also actively participate and debate issues and appreciate challenges and constraints in decision making process. The writer is in line with Tshabangu that when students are well prepared to be responsible citizens, they will participate in solving problems exist in their world. They will feel the sense of belonging of their community and even the world. They will think of solutions to problems that the world faces instead of thinking only about themselves. They will be rational and have empathy. If this can be achieved, the world will become a much better place to live in.

\section{METHOD}

This research aims at investigating what teachers can do through classroom management in order to prepare students to become responsible citizens. This research applies qualitative approach with library research as the method of gathering data. The data are 
form books and journal articles of research in classroom management.

\section{FINDINGS AND DISCUSSIONS}

Freiberg and Lapointe (2006) cite evidence that classroom management models are moving in the direction of recognizing the importance of "creating an environment of shared responsibility and learning" (in Fisch and Trumbull, 2008, p. 166) From this point of view, teacher's role is to facilitate students' increasing ability to take responsibility for their action as they mature. Teachers do not control students. The "emphasis on compliance does not fit well with current emphasis on learning through the social construction of knowledge and on helping students to become more autonomous and self-regulated learners" (Brophy, 1999,in Fisch and Trumbull, 2008). Therefore, classroom management based primarily on external control-the control from their teachers-may maintain order, but it fails our goals for classroom management: to promote students' learning of academic, social, and emotional skills and ability to put them to positive use in the world around them (Elias \& Schwab, 2006).

Numerous classroom management theorists and researchers have attempted to differentiated between management models that stress external control or obedience, on the one hand, and self-control, selfdiscipline, and responsibility, on the other (e.g. Bear 2005, Brophy 1999 curwin n Mendler 1988 dreikurs 1968, Freiberg 1999b Glasser 1992, Gordon, 1974, 2002, Kohn 1996, Weinstein 1999). Naturally, most people who write on this topic advocate an emphasis on developing students' selfcontrol over relying on short-term external control techniques. (Elias \& Schwab, 2006).

It can be seen that it is better to involve students in classroom management practice. The students have to be critical and do not only comply with what teachers tell them to do. They should be given room to think actions they will take and the reasons for doing what they will do. It will give them chances to be responsible of their actions and it will help them to mature and not simply grow older.

Below are the actions that teachers should put into practice in their classroom so that students see the examples of responsible citizens and also at the same time they put the actions into practice as well. The 
students are not taught what they have to do, but they can see how it is done. It is expected that the actions implemented in the classroom will become a habit that will shape them to become responsible citizens.

- Develop Democratic

\section{Classroom Rules and}

\section{Clear Expectations}

Rules and clear expectations are necessary for society and organization to function. Children have to know about what is acceptable and what is not. Learning to act with self-control and respect for others is predicated on having clear rules that define responsible behaviour in a particular environment (Elias \& Schwab, 2006). Since it is very important to shape students to become critical thinker, the rules that are set are discussed with the students. They do not have to simply comply with what teachers ask them to do. They have the rights to give input as what to include in the sets of rules that have to be obeyed by the class. These rules can also include rules for teachers, not only for the students.

When the rules are results of students' voice, it is likely that they will have more responsibility to obey it since they are involved in comprising the rules. It can be rules for simple things, for example, what the students have to do if they want to express their opinion. They can give their ideas of how this thing can be done. After that, it can be discussed which way is the most effective and efficient one. Everybody who would like to give any ideas has to give reasons as why they think the idea is good to implement. It also promotes critical thinking in that they have to give reasons for their thought, not simply expressing their idea without any logical reasons. For example, they can raise their hand and wait their name to be called by the teacher and then start talking because this way is effective and efficient and teach the students how to do turn taking and avoid more than one people talking at the same time. It may seem a simple matter but it helps maintain order in the classroom and at the same time it allows them to practice their responsibility to obey the rules that was set in the involvement of their ideas.

\section{- Share responsibility}


Teachers' acts of giving students as many opportunities possible to actively involved students in shared responsibility in and outside of classroom increase students commitment to the classroom and increases their motivation. It also decreases inappropriate behavior that results from frustration and the feeling of powerlessness. "Empowering students is the best way to encourage students to take responsibility and contribute rather than detract and destroy" (Elias \& Schwab, 2006, p. 334).

When they are given responsibilities, they will feel that they are worthy and it will increase their self-esteem as they feel capable of doing things. According to Elias \& Schwab (2006) "if we want children to learn responsibility, we have to give them as many opportunities as possible to experiment with it and grow comfortable, confident, and skilled at taking it"(p. 334).

Simple responsibilities such as maintaining classroom cleanliness and water plants and flowers can give students a good chance to practice responsibilities. It is good for them to know that they are expected to actively participate in maintaining things around them. According to Elias et al (1997) and Weinstein and Mignano (2003), this can make the class more manageable and productive and increase students' social-emotional competencies such as social responsibility and group decision making. (in Elias \& Schwab, 2006).

\section{- Set goals and plans}

Establish and work toward the achievement of specific short and long-term outcomes (Elias $\&$ Schwab, 2006). Students have to learn that it is important to have goals and plans and how to achieve them. These have to be set from the beginning of the class. It is their responsibilities in cooperation with the teacher to achieve thegoals.

\section{- Take A Problem-Solving Approach to Problems}

When there is a problem, it is better to see it as opportunities to think through possible solutions. Do not emphasise on how it happened but it is better to emphasise on the solutions. It is good to talk about why and how it happened so that it will not 
happen again next time, but it is better to focus more on the solutions. In doing it, involve students to think about the solutions. It also activates their critical thinking.

\section{- Care for others}

Teachers have to show empathy. Identify and understand students' thoughts and feelings. Teachers have to respect students and ask students to respect each otheract on the belief that others deserve to be treated with kindness and compassion as part of our shared humanity (Elias \&Scwab, 2006). Cooperative learning strategy is a good way to practice this. When they work in a group, they will learn and practice to respect each other. Moreover, students can help each other. It is hoped that they will continue this habit of helping each other outside the classroom as well. When it becomes a habit, they will make good citizens in which they will think of helping other people, not only think about themselves.

\section{- Personal best}

Martin (2006) found that one way of assisting students to set goals was to introduce the idea of personal best (in Roffey, 2011). Instead of competing with others, it is better to inform to students to compete with their best achievement, to compete with themselves. It is good because if they can do this, they will not see their friends as competitors, but friends who work together to achieve goals. To put this to reality, teachers should help students by not comparing one another. Instead, teachers can remind students of their best achievements and encourage them to work together to be better and better.

- Involve students in community activities

Teachers can take initiative to involve students in activities that involve larger groups of people outside the school community. May it be encourage them to donate for the poor or to visit children's hospitals to cheer up the patients with fatal diseases and remind them that they have 
friends and people who care.

These kinds of activities remind them that they are parts of larger group and to raise their awareness that they can help people around them, inside and outside the classroom. According to Elias \& Scwab (2006) "when students do active service in the classroom, the school, and the community, they develop a sense of contribution and responsibility."

\section{- Keep a Journal to}

\section{Evaluate}

Teachers can give example to students to have a journal that records important incidents. These can be good or bad ones. It is important to record the bad so that they can be evaluated. Both teachers and students can learn from their mistakes and put their best efforts so that the same mistakes will not happen again. The good ones are important, too. It is to record their best that they have to compete with so they can keep improving without having to compete with other people.

\section{CONCLUSION}

Those are some of the things that can be applied in and outside the classroom to promote the sense of responsibilities in students. The application can be adjusted to any level of the students, from elementary to secondary and tertiary. For elementary students, for example, teachers can choose shared responsibilities that are simple and it can get more complicated for higher level. If teachers can practice those steps, it is very likely that the students will be encouraged to do the same things. If the habits that promote the students to become responsible citizens are well developed, they will implement it as well in the society without having supervision or external control. They will be responsible citizens and the world will become a better place with more and more responsible citizens in it.

\section{REFERENCES}

Elias, M. J., \& Schwab, Y. (2006). From compliance to responsibility: Social and emotional learning and classroom management. In C. M. Evertson, \& C. S. Weinstein (Eds.), Handbook of classroom management: Research, practice, and contemporary 
issues (pp. 309-341). Mahwah, NJ: Lawrence Erlbaum Associates.

Fisch. C.R. \&Trumbull, E. (2008). Managing diverse classroom: How to Build on students' cultural strengths. Alexandria: Association for Supervision and Curriculum Development.

Garratt, D., \& Piper, H. (2003). Citizenship education and the monarchy: examining the contradictions.British Journal of Educational Studies, 51 (2), 128-148.

Koshewa, A. (1999). Discipline and democracy: Teachers on trial. Portsmouth, NH: Heineman.

Lewis et. al. (2005).Teachers' classroom discipline in Australia, China andIsrael.Teaching and Teacher Education. 21: 729-741.

Lewis, R., and Lovegrove, M. (1989).Parents' attitude to classroom discipline.Journal of Australian Studies, 13:25, 11-22.doi: $10.1080 / 14443058909387003$
Roffey, S. (2011). Changing behaviour in schools: Promoting positive relationships and wellbeing. Los Angeles, Calif: SAGE.

Tshabangu, I. P. (2006). Student participation and responsible citizenship in a non-polyarchy: An evaluation of challenges facing Zimbabwe's schools.International Education Journal, 7 (1), 56-65.

Republic of Indonesia, The Constitution of Indonesia (Amandement)

Republic of Indonesia, The Law Number 20 Year 2003 regarding National Education System

Republic of Indonesia, The Law Number 12 Year 2012 regarding Higher Education

Republic of Indonesia, Keputusan Direktur Jenderal Pendidikan Tinggi Nomor: 43/DIKTI/Kep/2006 tentang RambuRambu Pelaksanaan Kelompok Matakuliah Pengembangan Kepribadian di Perguruan Tinggi 